International Journal of Computer Science, Engineering and Information Technology (IJCSEIT), Vol.7, No.2, April 2017

\title{
HELPING PEOPLE WITH DOWN SYNDROME THROUGH AN USABILITY TESTING GUIDE PROPOSAL FOR MOBILE APPLICATIONS
}

\author{
Doris Cáliz ${ }^{1}$, Loïc Martínez ${ }^{1}$, Richart Cáliz² . \\ ${ }^{1}$ Department ETSIINF, DLSIIS, Madrid Polytechnic University, Campus de \\ Montegancedo 28660 , Boadilla del Monte , Madrid, Spain \\ ${ }^{2}$ Department of Computer Sciences FIS Group, National Polytechnic University, Ladrón \\ de Guevara E11-25 y Andalucía Quito, Ecuador
}

\begin{abstract}
The usability testing of mobile applications involving persons with Down syndrome is an issue that has not be comprehensively investigated and there is no single proposal that takes on board all the issues that could be taken into account[1]. This study aims to propose a practical guide "USATESTDOWN" to measure and evaluate the usability of mobile applications focusing on Down syndrome users and their primary limitations. The study starts with an analysis of existing methodologies and tools to evaluate usability and integrates concepts related to inspection and inquiry methods into a proposal. The proposal includes the opinions of experts and representative users; their limitations, the applicability during the development process and the accessibility. This guide is based on the literature review and the author's experience in several workshops where persons with Down syndrome used mobile devices.
\end{abstract}

\section{KEYWORDS}

Usability Testing, Mobile Applications, Cognitive Disability, Down Syndrome, Human Computer Interaction (HCI), Mobile Devices.

\section{INTRODUCTION}

Down syndrome (DS) is a genetic disorder with a worldwide incidence close to one in every 700 births but the risk varies with the mother's age. Persons with DS have impaired cognitive processing, language learning and physical abilities, as well as different personal and social characteristics [11]. Because Persons with DS have special characteristics, they need high levels of usability of the products they use. A usability testing methodology suitable for participants including persons with DS needs to be well designed taking on count their special skills [12].

The International Organization for Standardizations (ISO) bases usability on three main attributes: effectiveness, efficiency and satisfaction. Systems with good usability are easy to learn, efficient, not prone to errors and generate user satisfaction [10].

Testing products with representative users is a key factor for user-centred design. When such representative users are persons with disabilities the user testing process becomes a challenge and in this case evaluation methods based on heuristics and inspection could not attend the final user needs [3].

Persons Persons with Down syndrome have many difficulties to use the mouse and the keyboard because they have fingers shorter than usual [4]. Multi-touch technology helps to solve this problems when people use devices, such as mouse, keyboard or joystick, and enables users to take advantage of the direct manipulation interaction and the benefits of direct touch [9]. There are a big range of functional abilities in individuals with Down syndrome, related to the extent of 
impairment in the sensory and motor channels [5], memory, and cognition and communication skills [6]. These sensory and motor issues would need to be taken into consideration when researchers want to evaluate a mobile application in individuals with Down syndrome.

The authors have performed a detailed research on articles related with this topic and they have not found a guide to support the usability testing process for mobile applications focused on persons with Down syndrome [7]. After that, they they have evaluated the use of a tool called "Gestures" by a group of 100 persons with DS. The goal was to analyse the skills of these persons to perform basic gestures [8]. The authors found that DS children 5 to 10 year-old are able to perform most of the evaluated multi-touch gestures with success rates close to 100 per cent. This research study is designed to be a preliminary investigation of how users with Down syndrome could potentially utilize touch-screens gestures tasks to obtain a sense of some of the potential challenges to effective use of tablet computers for this population and to investigate how usability testing involving Persons with Down syndrome could be effectively performed. [9].The result of combining the literature review and the research experience in several workshops is the guide to perform usability testing when the participants are persons with DS. This guide is called "USATESTDOWN".

\section{Where is USATESTDOWN}

In the Human Computer Interaction area one of the most commonly used design philosophies to create high quality products for users is the User-Centred Design (UCD) approach[2] UCD refers to the philosophy that the intended user of a product should always be in the centred of the design process throughout all phases of the design[3]. Usability testing, according to Dumas \& Redish [4], aims to achieve the following five goals, to: Improve the product's usability, Involve real users in the testing, give the users real tasks to accomplish, Enable testers to observe and record the actions of the participants, Enable testers analyse the data obtained and make changes accordingly. USATESTDOWN is inside Evaluate the Design Requirements as we can see in Fig 1 .

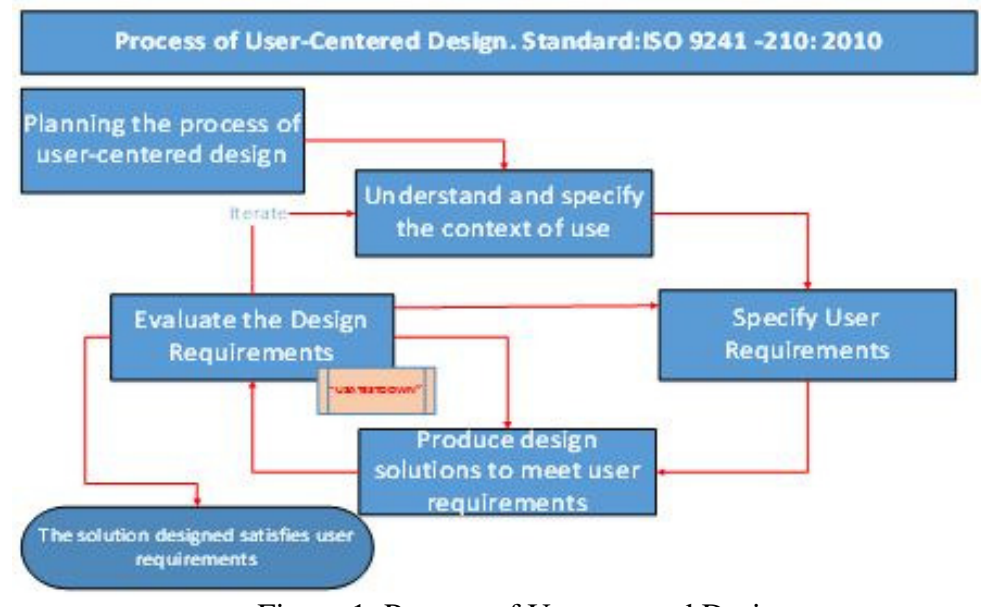

Figure 1: Process of User centred Design.

\section{RELATED WORK}

\section{a. Usability evaluation methods}

There are three types of usability evaluation methods: observational, analytical and inquiry evaluation methods [5]. Evaluation methods that collect dat ${ }^{\circ}$ a by observing users' experiences with a product are called observational evaluation methods. Usability testing, user-oriented view 
International Journal of Computer Science, Engineering and Information Technology (IJCSEIT), Vol.7, No.2, April 2017

and user performance testing are types of observational evaluation methods [6]. Methods that do not collect data from users' experiences but rely on the opinion of experts are called inspection or analytical evaluation methods. These methods have a product-oriented view. Examples of analytical evaluation methods are Heuristic Evaluation [7] Cognitive Walkthrough and Semiotic Inspection [8]. Inquiry methods have a user-oriented view. Inquiry methods tend to identify broad usability problems or opinions about a product as a whole such as user Satisfaction Questionnaires and Focus Groups [9].

\section{Usability Evaluation methods for mobile applications focused on persons with Down syndrome}

While there is some related research, it is incomplete. Devan does not consider mobile or touch screen devices. The author used an application called JECRIPE, this application works in a PC. Additionally it is not a Usability Testing Guide [10]. Kumin and Lazar did a usability evaluation to understand potential interface improvements and they suggest different tips to evaluate usability but it is not a Usability Test guide [11]. AR BACA SindD is a usability evaluation framework for an augmented reality framework for learners with DS but they did a specific evaluation in AR Systems but it is not a Usability test guide [12]. Adebesin, Kotzé show the important role of two evaluation methods in the usability [13.]The authors did not speak about touch screen, usability guide etc. (MEL-SindD) discusses the usability assessment of the courseware but it is not focus on mobile applications [14]

\section{b. Working Method Overview}

The guide reproduces the usual usability testing steps. The guide provides recommendations taking into account the needs of people with DS in the usability testing process.

In general, the working method has four main phases, as shown in Fig. 2. The process is iterative.

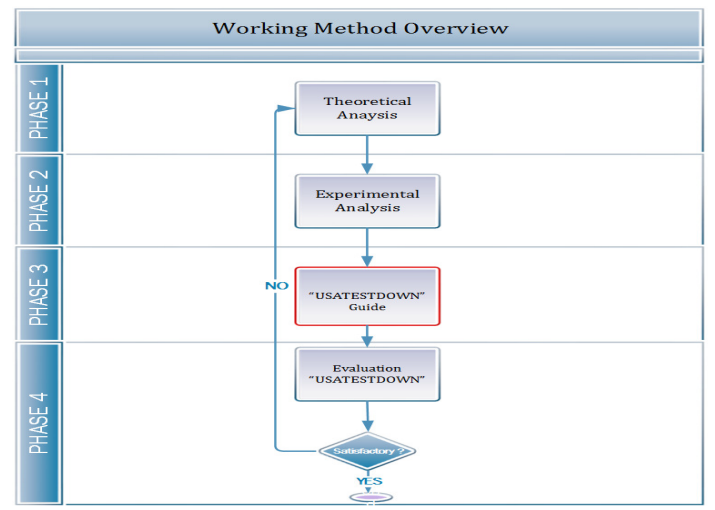

Figure 1: Working Method Overview

- Theoretical analysis. A state of the art on usability testing involving persons with Down syndrome.

- Experimental analysis. There have been made experiments on usability testing with persons with Down syndrome.

- The guideline "USATESTDOWN": This phase consists on the preparation of a guideline to perform usability testing involving persons with Down syndrome. The contents of the guideline, called "USATESTDOWN" are based on the results of phases 1 and 2. The development of the guideline will be iterative. Observational evaluation has been chosen as the method to be used in the usability testing. 
- Evaluation of "USATESTDOWN": The USATESTDOWN guideline will be evaluated with a set of experiments involving persons with Down syndrome in usability testing of mobile applications. The results of the evaluation will be used to improve the guideline.

\section{c. Usability testing previous contributions for mobile applications focused on persons with Down syndrome}

The most common method for evaluating how usable a product or system is usability testing, which involves testing prototypes with real users [4]. Participating users are given a set number of tasks that they have to perform using a prototype or a full system. Data on the effectiveness, efficiency and satisfaction of users are collected during testing. Generally, the usability process is divided into the following steps: 1. Recruit participants, 2. Establish the tasks, 3. Write the instructions, 4. Define the test plan, 5. Run the pilot test, 6. Refine the test plan, 7. Run the test session, 8. Analyse the collected objective, and 9. Report results.

We found 5 articles related with our topic after a Literature Review research. We used the definition of the main steps of usability testing [15] to analyse the contributions of each author on each usability testing step. We took the authors contributions in each point [7], [8], [9], [10], [11]. But is important notice they contribute only with the steps $1,2,3,5,7,8$, the steps $4,6,9$ were deleted because there are not contributions. We had the results in table 1. We can see there are several empty spaces, meaning that there are not contribution in those specific steps.

Table 1 Previous contributions of usability testing

\begin{tabular}{|l|l|l|l|l|l|l|}
\hline Paper & $\begin{array}{l}\text { 1. } \\
\text { Participants }\end{array}$ & 2. Tasks & $\begin{array}{l}\text { 3. } \\
\text { Instructions }\end{array}$ & $\begin{array}{l}\text { 5. Pilot } \\
\text { testing }\end{array}$ & $\begin{array}{l}\text { 7. } \\
\text { Testing }\end{array}$ & $\begin{array}{l}\text { 8. } \\
\text { Analyse }\end{array}$ \\
\hline$[10] 2013$ & $\mathrm{X}$ & $\mathrm{X}$ & & & & $\mathrm{X}$ \\
\hline$[13] 2010$ & $\mathrm{X}$ & $\mathrm{X}$ & & $\mathrm{X}$. & $\mathrm{X}$ & \\
\hline$[12] 2011$ & $\mathrm{X}$ & $\mathrm{X}$ & & & & \\
\hline$[11] 2012$ & & $\mathrm{X}$ & & $\mathrm{X}$ & & \\
\hline$[14] 2009$ & $\mathrm{X}$ & $\mathrm{X}$ & $\mathrm{X}$ & & $\mathrm{X}$ & \\
\hline
\end{tabular}

There is not a Guide to evaluate Usability in mobile applications focused on Down syndrome person. Consequently, the authors proposed the need to develop guidelines on the usability testing process in mobile applications involving participants with Down syndrome.

\section{d. Collected Experience}

USATESTDOWN is a guide to support usability testing of mobile applications when the participants are persons with DS. It has been developed by combining information collected from a literature review [15] and experience acquired during four workshops with approximately 100 people with DS [16][17]. We performed several workshops in different Special Dow Syndrome Centre in Spain (Asindown [16], Maria Corredentora [17], Apadema [18], Prodis [19]) as we show in the figure 1. We evaluated 122 persons, 69 children and 53 adults with Down syndrome to determinate the skills, behave and how they interact with mobile devices. 
International Journal of Computer Science, Engineering and Information Technology (IJCSEIT), Vol.7, No.2, April 2017

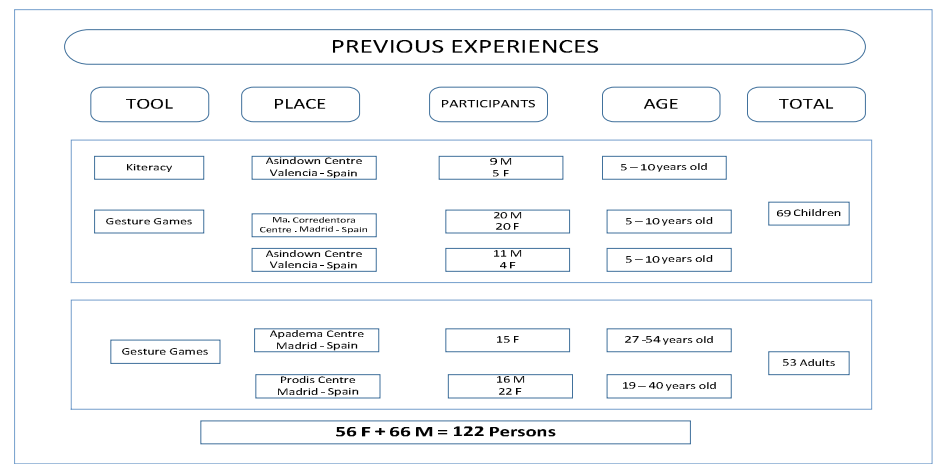

Figure 3: Collected Experience

\section{3. “USATESTDOWN" GUIDE Proposal}

USATESTDOWN is a guide to help usability tests of mobile applications focused on users with Down syndrome. Applying the usability testing guide USATESTDOWN, the evaluators can easily manage the usability test with applications on mobile devices for persons with Down syndrome in the different workshops following the different steps that the guide proposes. We describe the 9 steps of USATESTDOWN recommend for the authors, such as: [23], [24], [25], [24], and [26]. We describe this guide with specific activities in order to evaluate Mobile applications software focused on persons with Down syndrome. The flow of the process was adjusted to account for the reality of the persons with Down syndrome. We showed in Fig, the USATESTDOWN Guide process.

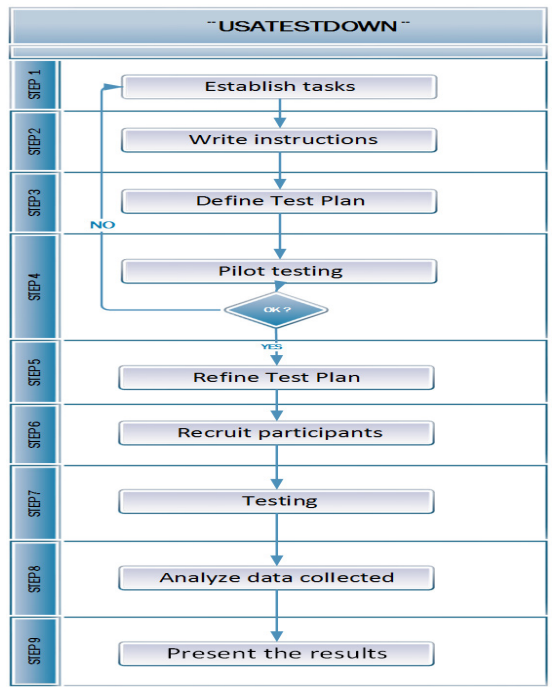

Figure 4: Process of Usability Testing as defined in USATESTDOWN

After the USATESTDOWN figure scheme we have 4 tables from number II until $\mathrm{X}$ with the following information:

- Step: The step name based on the Usability Test process

- Definition: According with the authors [18], [19], [20] what we should expect in this point. 
- Bibliography Research:

Bibliography Suggestion: A collection about what the authors propose in this step [7] [8] [9] [10] [11].

$>$ Real Experience: The real results obtained after to apply the author guideline. It is the information collected with several workshops, it means the experience that we collected with this experiments. The workshops were explained on chapter 2.

\section{- Usatestdown:}

UsatestDown Guideline : Contribution of the proposal Guide. This part contain the experience before and after to create UsaTest down because we tested the proposal guide with several workshops and we improve every time making finally a complete guide.

$>$ Got From Experience : The experience we had after perform the workshops and the reason why we propose the guideline. It is the justification or reason to propose the recommendation. This

- Documents: Documents to support the step adapted specially to persons with DS.

1. Establish the tasks.

Establish the tasks

Table 2: Usatestdown:

\begin{tabular}{|c|c|c|}
\hline \multicolumn{3}{|r|}{ USATESTDOWN } \\
\hline Step: & \multicolumn{2}{|l|}{ Establish the tasks } \\
\hline Definition & \multicolumn{2}{|c|}{$\begin{array}{l}\text { This step consists of defining the tasks that the participants will complete in the usability tests. These tasks will be } \\
\text { identified in pre-development phases to identify which of them will form a part of the evaluation that will include } \\
\text { tasks that appear in certain usability specifications, as well as other representative tasks. }\end{array}$} \\
\hline \multirow{5}{*}{$\begin{array}{l}\text { Bibliograph } \\
y \text { Research }\end{array}$} & BIBLIOGRAPHY SUGESTION & REAL EXPERIENCE \\
\hline & $\begin{array}{l}\text { - [17] Holds a 30-minute training } \\
\text { session. }\end{array}$ & $\begin{array}{l}\text { - We did not use because was too much time, participants lost the } \\
\text { concentration and it is tired to them }\end{array}$ \\
\hline & $\begin{array}{l}\text { - [17] DEVAN method to work } \\
\text { directly with children with DS. }\end{array}$ & $\begin{array}{l}\text { - We tried to apply but was too complicated and was focused only to } \\
\text { childrens }\end{array}$ \\
\hline & $\begin{array}{l}\text { - [19] Submis sion of evaluation } \\
\text { criteria, Signature of anonymity and } \\
\text { confidentiality }\end{array}$ & - We aplyed this suggestion because was required by the Tutors. \\
\hline & $\begin{array}{l}\text { - [20] Divides the test tasks into } \\
\text { several phases }\end{array}$ & - We dividen into 9 phases using the formal Usability test process \\
\hline \multirow{5}{*}{$\begin{array}{l}\text { Csatestdow } \\
n\end{array}$} & USATESTDOWN GUIDELINE & GOT FROM EXPERIENCE \\
\hline & $\begin{array}{l}\text { - Take the participants with the } \\
\text { same level of disability. }\end{array}$ & $\begin{array}{l}\text { - We selected participats taking on count only age but they had different } \\
\text { skills levels and what might be simple for one may be more complex for } \\
\text { others. }\end{array}$ \\
\hline & $\begin{array}{l}\text { - The tasks should not have a high } \\
\text { complex level. The difficult scale } \\
\text { shoud be of } 1 \text { to } 3 \text {, where } 1 \text { is } \\
\text { esaier, the thask should take } 1 \text {. }\end{array}$ & $\begin{array}{l}\text { - The participants showeda problem to reach the normal objectives if the } \\
\text { task is too complex, it means the level must to start on } 1 \text { and if it is } \\
\text { necessary increase the task difficut level but the higerst level is not } \\
\text { recommended. }\end{array}$ \\
\hline & $\begin{array}{l}\text { - The ses sion should be done in } 10 \\
\text { minute sessions for each person, }\end{array}$ & $\begin{array}{l}\text { - The participantes had a problem to keep the attention for more than } 10 \\
\text { minutes. because they will get tired easlily. This point will allow the } \\
\text { individual to evaluate the application with curiosity without getting } \\
\text { overwhelmed or bored. }\end{array}$ \\
\hline & $\begin{array}{l}\text { - Do not limit to the participants the } \\
\text { time. }\end{array}$ & $\begin{array}{l}\text { The perticipants will stress and become confused if they have a time limit for the } \\
\text { task. We could ses on the sessions that the participants were getting afraid with } \\
\text { the topic task limitad with time. They could feel nervous. }\end{array}$ \\
\hline
\end{tabular}


2. Write the instructions

Table 3: Usatestdown: Write the instructions

\begin{tabular}{|c|c|c|}
\hline \multicolumn{3}{|c|}{ USATESTDOWN } \\
\hline Step: : & & Write the instructions \\
\hline Definition & \multicolumn{2}{|c|}{ Specify the instructions given to the users (oral, written, or both) to perform each task } \\
\hline $\begin{array}{l}\text { Bibliography } \\
\text { Research }\end{array}$ & \multicolumn{2}{|l|}{ NO CONTRIBUTIONS } \\
\hline \multirow[t]{5}{*}{ Usatestdown } & USATESTDOWN GUIDELINE & GOT FROM EXPERIENCE \\
\hline & $\begin{array}{l}\text { - Use only the oral way to explain } \\
\text { the task to the participants }\end{array}$ & $\begin{array}{l}\text { - Before completing the test, it is necessary to give a presentation to the } \\
\text { pers ons who will participate with the evaluation. They should interact } \\
\text { with the aplication on a training way. The Facilitator should explain the } \\
\text { project objectives on a slowly way }\end{array}$ \\
\hline & $\begin{array}{l}\text { - Ask the participant if he/she is a } \\
\text { willing partipant. }\end{array}$ & $\begin{array}{l}\text { - Evaluator must to ask if the participant would like to participate even } \\
\text { if the Tutor recomeded this participant. The willingness of the } \\
\text { participants to participate is very important to have real dates. They } \\
\text { could feel pushed forthe Tutors and thetutor coud not realize about it. }\end{array}$ \\
\hline & - Speak slowly and repeat the task & $\begin{array}{l}\text { - Speak slowly andrepeat if is necessary, participants use to lost the } \\
\text { attention easily }\end{array}$ \\
\hline & $\begin{array}{l}\text { - Perform the sesion with the } \\
\text { participant individualy. }\end{array}$ & $\begin{array}{l}\text { - Participants need to have extra attention and the evaluator should put } \\
\text { all his attention on the participant to be sure he understo od the task. }\end{array}$ \\
\hline
\end{tabular}

3. Define the test plan

Table 4: Usatestdown: Define the test plan

\begin{tabular}{|c|c|c|}
\hline \multicolumn{3}{|c|}{ USATESTDOWN } \\
\hline Step : & \multicolumn{2}{|c|}{ Define the test plan } \\
\hline Definition & \multicolumn{2}{|c|}{$\begin{array}{l}\text { It is necessary to specify the protocol with alternative activities, such as, welcome, interview preview, } \\
\text { completing the tasks by observing the user, satisfaction questionnaire, personal interview to collect } \\
\text { qualitative information, etc. It is recommended to write an introductory commentary to express a welcome } \\
\text { to the users. It is necessary, as part of these instructions, to collect the data needed by the users to complete } \\
\text { the tasks. }\end{array}$} \\
\hline \multirow{2}{*}{$\begin{array}{l}\text { Bibliography } \\
\text { Research: }\end{array}$} & BIBLIOGRAPHY SUGESTION & REAL EXPERIENCE \\
\hline & $\begin{array}{l}\text { [20] The evaluation was done on the } \\
\text { users on a one-to-one basis. }\end{array}$ & $\begin{array}{l}\text { It was necessary evaluate every participant on a individual } \\
\text { way otherweise they lost the concentration. They need many } \\
\text { attention and support. }\end{array}$ \\
\hline \multirow[t]{5}{*}{ Usatestdown } & USATESTDOWN GUIDELINE & GOT FROM EXPERIENCE \\
\hline & $\begin{array}{l}\text { - The demographic survey must have } \\
\text { only general information not lasts names. }\end{array}$ & $\begin{array}{l}\text { - It is necessary to complete a demographic survey including } \\
\text { name, age, gender, experience with mobile devices. It must to } \\
\text { have only general information, even it could use a fake name } \\
\text { because family, tutors and participants are so reserved wit } \\
\text { information that it would allow them to be identifier. Never } \\
\text { take last names. Don't push the persons to answer if they don't } \\
\text { want, it may generate a bad atmosphere to work. This is like } \\
\text { the test that was used in the workshops and can be found in } \\
\text { Annex 1. It should be completed by the evaluator. }\end{array}$ \\
\hline & $\begin{array}{l}\text { - Aplly the User satisfaction survey only } \\
\text { with } 3 \text { answers. USATESRDOWN tets } \\
\text { is recommended. }\end{array}$ & $\begin{array}{l}\text { - It is important to prepare a user satisfaction survey with a } \\
\text { scale of no greater than } 3 \text { categories and, if possible, with } \\
\text { graphics of faces (happy, neutral, sad). We tried to work with } \\
5 \text { answers but it was confusing to the participants. Aditionally } \\
\text { we had a meeting with the students psicologist supervisors and } \\
\text { they also recommended only } 3 \text { levels }\end{array}$ \\
\hline & $\begin{array}{l}\text { - Don't use documents with text to the } \\
\text { participants. If you need to give } \\
\text { documents it is better with graphics or } \\
\text { don't not use documents }\end{array}$ & $\begin{array}{l}\text { - Avoid providing documents with long text to the persons } \\
\text { who will participate in the test Generally, persons with DS } \\
\text { have vision problems and it is taxing for them to read and } \\
\text { speak. It is recommended that the instructions be given } \\
\text { verbally and in a graphic form that is simple, allowing them to } \\
\text { understand the information. In the first workshop session, we } \\
\text { wrote test to explain to the participants the steps that they } \\
\text { should follow but they had probles to read or pronunce and to } \\
\text { understand. It si better to avoid }\end{array}$ \\
\hline & $\begin{array}{l}\text { - Write short questions only with } 3 \\
\text { answers }\end{array}$ & $\begin{array}{l}\text { - Write short questions only with } 3 \text { answers (not, may be, yes), } \\
\text { in this specific order because if they find fist the option YES } \\
\text { they will not read the rest of te options. If you want to ask } \\
\text { about quantity answer posibility is (few, many, too many). It } \\
\text { means only } 3 \text { answers. }\end{array}$ \\
\hline
\end{tabular}




\begin{tabular}{|c|c|}
\hline $\begin{array}{l}\text { - Write questions focused on the } \\
\text { applications and try to make understand } \\
\text { the participants how important is to say } \\
\text { the truth }\end{array}$ & $\begin{array}{l}\text { - The participants are likely to provide friendly answers } \\
\text { whether or not they like the application because they tend to } \\
\text { be friendly persons. Persons with Down Syndrome are so } \\
\text { friendly and they like to make friends, this is their normal } \\
\text { behaviour, we had seeral cases with participants whoes answer } \\
\text { the questionary saying the aplication was esy to understand, } \\
\text { but when we analized the results with the log aplicaction the } \\
\text { participants could not get success on the task or the success } \\
\text { level was so low. Aditionally when we asked Did you like the } \\
\text { aplication?' No body said NO, it showed us that it was not the } \\
\text { rally truth. The wanted just to be friendly. }\end{array}$ \\
\hline $\begin{array}{l}\text { - Participation of the expert tutors is } \\
\text { requiered }\end{array}$ & $\begin{array}{l}\text { - The participation of the expert tutors is very important as } \\
\text { their experience greatly contributed to the implementation of } \\
\text { the test, following the guide. Additionally, it is critically } \\
\text { important to include the expert tutors with the interaction with } \\
\text { the participants' }\end{array}$ \\
\hline $\begin{array}{l}\text { - The sessions will be facilitated and } \\
\text { observed by only one facilitator to one } \\
\text { participant }\end{array}$ & $\begin{array}{l}\text { - It is because on the workshops the participants were shy } \\
\text { when they see many new persons in the room. }\end{array}$ \\
\hline $\begin{array}{l}\text { - Persons need to be encouraged to } \\
\text { participate and facilitator should stress } \\
\text { the value of the child's input and show } \\
\text { appreciation and gratitude. }\end{array}$ & $\begin{array}{l}\text { - This is a task that the facilitator should do. People with DS } \\
\text { like to feel they are helping to another people. They will feel } \\
\text { motivated. }\end{array}$ \\
\hline $\begin{array}{l}\text { - The educators of people with DS should } \\
\text { be present at the moment of perform the } \\
\text { sesion. }\end{array}$ & $\begin{array}{l}\text { - This is very necessary on the sesion because the articipants } \\
\text { will feel sure and with a high confidence level. }\end{array}$ \\
\hline $\begin{array}{l}\text { - Give the participant the device for long } \\
\text { time to execute the game (or task) task at } \\
\text { home. Application should have a datalog } \\
\text { to record. }\end{array}$ & $\begin{array}{l}\text { - We suggest an evaluation stage where devices are given back } \\
\text { to them to determine how much time is necessary for them to } \\
\text { work independently from the tutors and then independent of } \\
\text { the application and able to do the activity without the support } \\
\text { of a tutor or the application. }\end{array}$ \\
\hline - Apply at least 2 evaluation methods & $\begin{array}{l}\text { - It means oservational method to analise the user behaviour } \\
\text { and the tool should have a log or a way to evaluate if the task } \\
\text { was completed susscesfully or not, aditionally you shoul use a } \\
\text { satisfaction cuestionary, in this case the proposal recommend } \\
\text { the SUS Questionary adapted to persons with Down } \\
\text { Syndrom. }\end{array}$ \\
\hline $\begin{array}{l}\text { - Establish objective metrics with a } \\
\text { completion time for the task, error rate, } \\
\text { etc. }\end{array}$ & $\begin{array}{l}\text { - Performing the workshops we could notise the time is not a } \\
\text { good parameter to take on count because when we said } \\
\text { persons with down syndrome participants that they should do } \\
\text { the task on a specific time, inmediatly they were scared becase } \\
\text { they thought is an evaluation about how smart they are and it } \\
\text { is obviosly a big problem even to persons without down } \\
\text { syndrome. }\end{array}$ \\
\hline $\begin{array}{l}\text { - The participants should have pre } \\
\text { training about the aplication } \\
\text { - }\end{array}$ & $\begin{array}{l}\text { It mens tutor should teach to the participants how the } \\
\text { aplication work and the should interact par minutes with the } \\
\text { aplication before the real test. }\end{array}$ \\
\hline $\begin{array}{l}\text { - Establish subjective metrics such as } \\
\text { sucess, frustration, satisfaction, etc. }\end{array}$ & $\begin{array}{l}\text { - While the participants are using the application. Success: } \\
\text { Defined as the completion of a task done correctly and without } \\
\text { help. Satisfaction: When the user gets the correct result easily, } \\
\text { when the user shows happiness when interacting with the } \\
\text { application, etc. Frustration: When the user has problems } \\
\text { answering a tutor's questions, when the user gives an incorrect } \\
\text { answer, when the user doesn't understand the process, etc. }\end{array}$ \\
\hline - Schedule a break halfway & $\begin{array}{l}\text { - It means, through the test session and remind the participants } \\
\text { that they can stop at anytime. Don't push participants }\end{array}$ \\
\hline $\begin{array}{l}\text { - Record videos about the participants } \\
\text { sesions but without faces. }\end{array}$ & $\begin{array}{l}\text { - To evaluate Success, frustration, satisfaction you could use } \\
\text { the videos recorder during the workshop or sesion or at te } \\
\text { same time the tutor could take on count measure of every } \\
\text { tasks, how many times the participant showed this reaction. }\end{array}$ \\
\hline $\begin{array}{l}\text { - Hold a meeting prior to executing the } \\
\text { test }\end{array}$ & $\begin{array}{l}\text { - Because it is very important to break the ice with the } \\
\text { participant so that they feel safe and trusting of the process at } \\
\text { the workshop, This is a way to make friendly and relaxin the } \\
\text { work enviroment }\end{array}$ \\
\hline
\end{tabular}


International Journal of Computer Science, Engineering and Information Technology (IJCSEIT), Vol.7, No.2, April 2017

\begin{tabular}{|c|c|c|}
\hline & $\begin{array}{l}\text { - Observation method needs facilitator to } \\
\text { record all children action, behaviours and } \\
\text { facial expressions while observing } \\
\text { children playing the game. }\end{array}$ & $\begin{array}{l}\text { - In order to guide facilitator, an observation checklist is } \\
\text { needed to analyse the participants behavoiur. }\end{array}$ \\
\hline & $\begin{array}{l}\text { - The evaluator should evaluate every } \\
\text { participant on a individual way. }\end{array}$ & $\begin{array}{l}\text { - The evaluatior needs to catch the participat atention, until to } \\
\text { be sure the participant understood the task. Some times is } \\
\text { necessary ask the participants to see the evaluator eyes } \\
\text { otherweise they focus their attention on another thing they } \\
\text { could see. }\end{array}$ \\
\hline & $\begin{array}{l}\text { - Do not use the technique of "thinking } \\
\text { out loud" }\end{array}$ & $\begin{array}{l}\text { - Because the majority of the participants have difficulty } \\
\text { expressing themselves }\end{array}$ \\
\hline Documents & \multicolumn{2}{|c|}{$\begin{array}{l}\text { The documents should be printed } \\
\text {-UsatestDown Demographic Questionary (Annexes) } \\
\text {-UsatestDown SUS Questionary adapted to persons with Down Syndrome focused } \\
\text {-UsatestDown SUS Questionary to Tutors focused in the whole process (Annexes ) }\end{array}$} \\
\hline
\end{tabular}

4. Run the pilot test

Table 5: Usatestdown: Run the pilot test

\begin{tabular}{|c|c|c|}
\hline \multicolumn{3}{|r|}{ USATESTDOWN } \\
\hline Step : & & Run the pilot test \\
\hline $\begin{array}{l}\text { Definitio } \\
n\end{array}$ & \multicolumn{2}{|c|}{$\begin{array}{l}\text { Execute the test protocol using the welcome, the written instructions, completing the observations, measuring times, } \\
\text { completing the interviews, etc. in order to analyze if the proposed process functions as expected. In the case that it is } \\
\text { not, it should be writen as the protocol describe. }\end{array}$} \\
\hline \multirow{3}{*}{$\begin{array}{l}\text { Bibliogra } \\
\text { phy } \\
\text { Research } \\
\quad:\end{array}$} & BIBLIOGRAPHY SUGESTION & REAL EXPERIENCE \\
\hline & $\begin{array}{l}\text { [19] Involve field evaluation with a } \\
\text { larger and more diverse user group to } \\
\text { assess the extent }\end{array}$ & $\begin{array}{l}\text { This recommendation does not define the number. In our case we } \\
\text { recommend at least } 10 \text { users. }\end{array}$ \\
\hline & [6] Don't use passwords & We never used passwords \\
\hline \multirow{11}{*}{$\begin{array}{c}\text { Usatestd } \\
\text { own }\end{array}$} & USATESTDOWN GUIDELINE & GOT FROM EXPERIENCE \\
\hline & $\begin{array}{l}\text { - Record on video the interaction of } \\
\text { the person with the mobile device }\end{array}$ & $\begin{array}{l}\text { - It is recommended and very important in order to qualitatively evaluate } \\
\text { their interaction with it when we review the videos. Be careful not to film } \\
\text { faces and to obtain authorization in order to complete this point. }\end{array}$ \\
\hline & $\begin{array}{l}\text { - Ask for parents permission if it is } \\
\text { necessary to film faces, }\end{array}$ & $\begin{array}{l}\text { - The evaluator should be really polite because this is a sensitive topic. Some } \\
\text { times is necessary the fathers autorization to record participants faces . }\end{array}$ \\
\hline & $\begin{array}{l}\text { - To the pilot test is necessary only one } \\
\text { participant }\end{array}$ & $\begin{array}{l}\text { - It is recommended that the pilot test is done through a small samples but in } \\
\text { this case it means only one person because the evaluator will notice with the } \\
\text { second participant the mistake will be the same. This will allow a definition } \\
\text { of the first process errors without needing to involve all of the participants } \\
\text { in the process, repeating the same error. }\end{array}$ \\
\hline & $\begin{array}{l}\text { - The tutors or professors should be } \\
\text { present on the evaluation sesion. }\end{array}$ & $\begin{array}{l}\text { - During the entire evaluation process or user participation, it is necessary } \\
\text { that the tutors or professors with whom they are interacting on a daily basis } \\
\text { are present and provide a sense of support as we could see in the sessions } \\
\text { we performed }\end{array}$ \\
\hline & $\begin{array}{l}\text { - The facilitator will sit next to the } \\
\text { child during the session to take note } \\
\text { and solve participant questions }\end{array}$ & $\begin{array}{l}\text { - The facilitator will sit next to the child during the session and his/her role } \\
\text { is to fill in the observation form while interacting with the child to make } \\
\text { them feel at ease. We rocomend the participant doesnot write himself the } \\
\text { questionary. They use to have problems to write or read. }\end{array}$ \\
\hline & $\begin{array}{l}\text { - Two questionnaires need to be } \\
\text { assessed, they are proposed for } \\
\text { USATESTDOWN }\end{array}$ & $\begin{array}{l}\text { - There are two questionnaires that need to be assessed which are } \\
\text { demographic questionnaire and post task questionnaire but we propose } \\
\text { specifics questionaies adapted to participants with Down Syndrome. We } \\
\text { designed this questionaries with Special Psicologist whoes work every day } \\
\text { with those participants, taking as base the SUS questionarie. }\end{array}$ \\
\hline & $\begin{array}{l}\text { - Post task questionnaire will be } \\
\text { conducted right after each test session } \\
\text { with the help from the Tutor or } \\
\text { Parent }\end{array}$ & $\begin{array}{l}\text { - Post task questionnaire will be conducted right after each test session with } \\
\text { the help from the Tutor or Parent. Is is neceary make the testas soon as } \\
\text { posible, not the next day because participants forget what they did. } \\
\text { Facilitador should be close just in case the participant have a dubt. }\end{array}$ \\
\hline & $\begin{array}{l}\text { - Take note of the times when the } \\
\text { participant asks for help. }\end{array}$ & $\begin{array}{l}\text { - The evaluator mus to take note of the times when the participant asks for } \\
\text { help. }\end{array}$ \\
\hline & - Take a pause & $\begin{array}{l}\text { - Schedule a break halfway through the test session and remind the } \\
\text { participants that they can stop at anytime. Don't push to the students to do } \\
\text { everything at the same time. }\end{array}$ \\
\hline & $\begin{array}{l}\text { - Use simple words when directing the } \\
\text { participant }\end{array}$ & $\begin{array}{l}\text { - When you explain to the participants the tasks, process, objectives etc, you } \\
\text { should use a easy vocabulary, people with down syndrome showed they } \\
\text { don't understand difficult words and they lost attention }\end{array}$ \\
\hline
\end{tabular}


International Journal of Computer Science, Engineering and Information Technology (IJCSEIT), Vol.7, No.2, April 2017

\begin{tabular}{|c|l|}
\hline & $\begin{array}{l}\text { Speak slowly slow and some times is } \\
\text { necessary repeat the same idea }\end{array}$ \\
\hline $\begin{array}{c}\text { Docume } \\
\text { nts }\end{array}$ & $\begin{array}{l}\text { The documents should be applied } \\
\text {-UsatestDown Demographic Questionary (Annexes) } \\
\text {-UsatestDown SUS Questionary adapted to persons with Down Syndrome focused in the whole process } \\
\text {-UsatestDown SUS Questionary to Tutors focused in the whole process (Annexes ) }\end{array}$ \\
\hline
\end{tabular}

5. Refine the test plan after analysing the results of the pilot tests.

Table 6: Usatestdown: Refine the test plan after analyzing the results of the pilot tests.

\begin{tabular}{|c|c|c|}
\hline \multirow{2}{*}{\multicolumn{3}{|c|}{$\begin{array}{c}\text { USATESTDOWN } \\
\text { Refine the test plan after analysing the results of the pilot tests. }\end{array}$}} \\
\hline Step : & & \\
\hline Definition & \multicolumn{2}{|c|}{$\begin{array}{l}\text { Once analyzing the results of the pilot test, modifications may be made to the protocol, instructions, task data, task } \\
\text { sequencing, interview questions, etc., if necessary. }\end{array}$} \\
\hline $\begin{array}{l}\text { Bibliograp } \\
\quad \text { hy } \\
\text { Research: }\end{array}$ & \multicolumn{2}{|l|}{ NO CONTRIBUTIONS } \\
\hline \multirow{4}{*}{$\begin{array}{l}\text { Usatestdo } \\
\text { wn }\end{array}$} & USATESTDOWN GUIDELINE & GOT FROM EXPERIENCE \\
\hline & $\begin{array}{l}\text { - Validate the tasks what the } \\
\text { evaluator would you like to change } \\
\text { with the Tutors }\end{array}$ & $\begin{array}{l}\text { - If an error is encountered in the test pilot, it is necessary to make an } \\
\text { immediate change to the plan and execute a second session but it shoul be } \\
\text { aproved by the DS persons Toutors because evaluator could consider } \\
\text { aditionals actions as normal but Tutors could have another point of view }\end{array}$ \\
\hline & $\begin{array}{l}- \text { Write the changes will be done } \\
\text { and explain the reason why it was } \\
\text { made. }\end{array}$ & $\begin{array}{l}\text { - It could help to understand the DS persons behaviour with the aplication. } \\
\text { It shoult take on count to make inform with the final analysis }\end{array}$ \\
\hline & $\begin{array}{l}\text { It Is requiered a formal document } \\
\text { signed by the participants tutor to } \\
\text { make changes. }\end{array}$ & $\begin{array}{l}\text { - If the inicial Test Plan has to be changed, the evaluator should have a } \\
\text { document signed by the Tutor with the aprobation. With persons with Down } \\
\text { syndrome is very important follow this rules. }\end{array}$ \\
\hline
\end{tabular}

\section{Recruit participants}

Table 7: Usatestdown: Recruit participants

\begin{tabular}{|c|c|c|}
\hline \multicolumn{3}{|c|}{ USATESTDOWN } \\
\hline Step : & \multicolumn{2}{|r|}{ Recruit participants } \\
\hline Definition & \multicolumn{2}{|c|}{ Process to determine the type and number of participants needed for the usability tests. } \\
\hline \multirow{2}{*}{$\begin{array}{l}\text { Bibliograph } \\
\text { y Research: }\end{array}$} & BIBLIOGRAPHY SUGESTION & REAL EXPERIENCE \\
\hline & $\begin{array}{l}\text { - [17] Recomended } 4 \text { participants ,[19] } 6 \\
\text { participants [18] } 3 \text { or } 5 \text { to five participants } \\
\text { - [24] work with two paediatricians, primary } \\
\text { school teachers and } 11 \text { children with DS. } \\
\text { - [6] Nielsen's study showed that a group of } \\
\text { five users with different background, mixed } \\
\text { gender and aged five to six years old, they } \\
\text { were able to find about } 80 \% \text { of the findings } \\
\text { in a system. }\end{array}$ & $\begin{array}{l}\text { About number of particpants We could see with smaller } \\
\text { groups as } 2 \text { or } 3 \text { the difference between them is big because } \\
\text { every student have special skills and the resuts did not } \\
\text { define a clear behavior pattern } \\
\text { In this specific case } 6 \text { persons was not enough. }\end{array}$ \\
\hline \multirow{4}{*}{$\begin{array}{c}\text { Usatestdow } \\
n\end{array}$} & USATESTDOWN GUIDELINE & GOT FROM EXPERIENCE \\
\hline & $\begin{array}{l}\text { - It is necessary that evaluators determine } \\
\text { the cognitive disabilities level of the } \\
\text { participants that they need, only the age is } \\
\text { not a parameter to be on count. }\end{array}$ & $\begin{array}{l}\text { - To establish the tasks, it should be considered that the } \\
\text { participants have different levels of abilities and what } \\
\text { might be simple for one may be more complex for others. }\end{array}$ \\
\hline & $\begin{array}{l}\text { - There should ge at least } 10 \text { participants to } \\
\text { the evaluation }\end{array}$ & $\begin{array}{l}\text { - We could see with smaller groups as } 2 \text { or } 3 \text { the difference } \\
\text { between them is big because every student have special } \\
\text { skills and the resuts did not define a clear behavior pattern. }\end{array}$ \\
\hline & $\begin{array}{l}\text { - Send clear information about the session } \\
\text { objective to the Technology Department, if } \\
\text { they are ineterested on the research and they } \\
\text { could find a aportation to the centre they } \\
\text { would contact with the Directives } \\
\text { explaining the advantages they could have. }\end{array}$ & $\begin{array}{l}\text { - The first step in recruiting young participants is sending } \\
\text { information about the study to the places whoes are } \\
\text { working with the particpants profile that we want to work, it } \\
\text { means, tere are differents kinds of Centres working with } \\
\text { down Syndrome depending of the students levels skills. }\end{array}$ \\
\hline
\end{tabular}




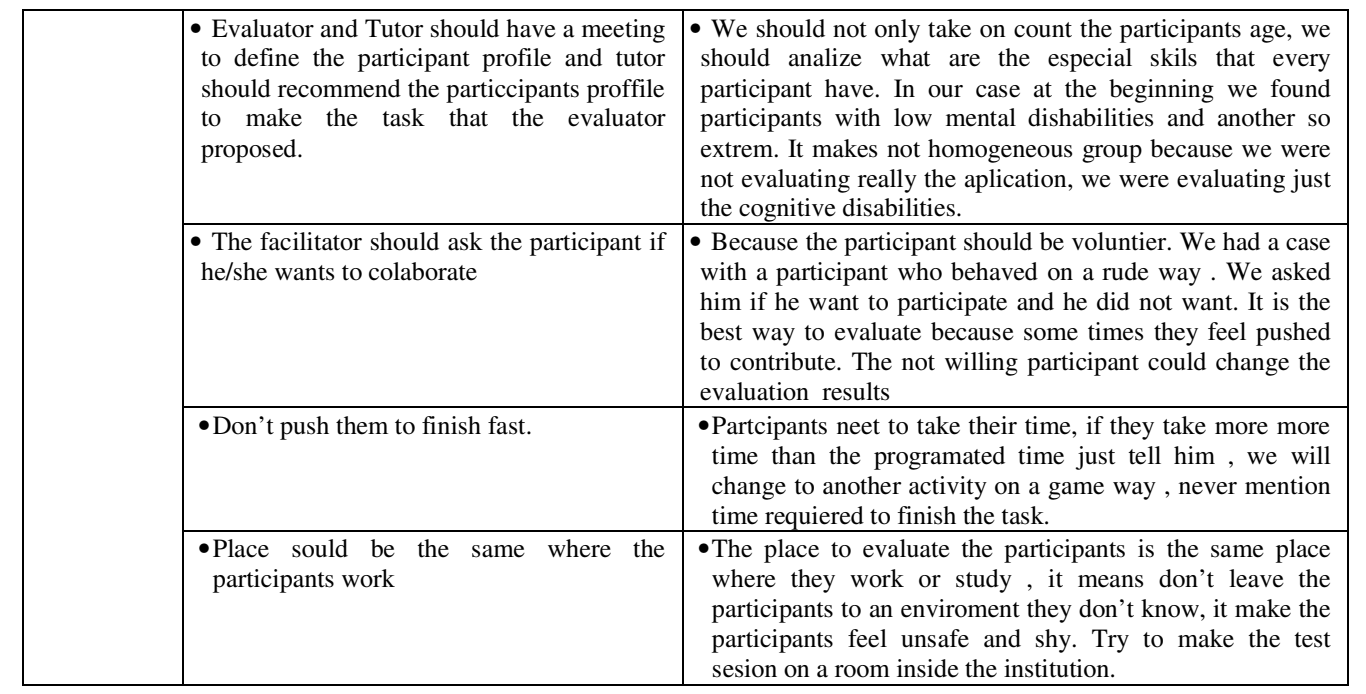

\section{Run the test session}

Table 8: Usatestdown: Run the test session

\begin{tabular}{|c|c|c|}
\hline \multicolumn{3}{|c|}{ USATESTDOWN } \\
\hline Step : & & Run the test session \\
\hline Definition & \multicolumn{2}{|c|}{$\begin{array}{l}\text { This is the essential part of the evaluation because it is here that the usability evaluation is completed. (1) } \\
\text { Welcome; (2) Ask the participants to carry out the tasks; (3a) If performance is measured, measure the times, } \\
\text { (3b) If performance is not measured, interrupt the user to clarify their decisions; (4) Note the number of errors } \\
\text { and other objective data; (5) Distribute a satisfaction questionnaire and complete a personal interview. }\end{array}$} \\
\hline \multirow{3}{*}{$\begin{array}{l}\text { Bibliograph } \\
\text { y Research: }\end{array}$} & BIBLIOGRAPHY SUGESTION & REAL EXPERIENCE \\
\hline & $\begin{array}{l}\text { [20] The evaluation sould be made on } \\
\text { the users on a one-to-one basis. }\end{array}$ & We noticed this making the test sessions \\
\hline & [19] Support to the participants & $\begin{array}{l}\text { The suport to the participants was really important because when } \\
\text { the participants can not perform something they have te dendence } \\
\text { to be passive. }\end{array}$ \\
\hline \multirow{9}{*}{$\begin{array}{l}\text { Usatestdow } \\
\mathrm{n}\end{array}$} & USATESTDOWN GUIDELINE & GOT FROM EXPERIENCE \\
\hline & $\begin{array}{l}\text { - Do not complete the final test on the } \\
\text { same day as the pilot testing }\end{array}$ & $\begin{array}{l}\text { - Because the users will be tired and confused if the first pilot } \\
\text { process failed. }\end{array}$ \\
\hline & $\begin{array}{l}\text { - Record everithing the participant make } \\
\text { and all his body behavior }\end{array}$ & $\begin{array}{l}\text { - This information is very important to make the cualitative } \\
\text { analysis }\end{array}$ \\
\hline & - Make a pause during the test & $\begin{array}{l}\text { - Schedule a break halfway through the test session and remind the } \\
\text { participants that they can stop at anytime. Take note of the times } \\
\text { when the participant asks for help. }\end{array}$ \\
\hline & $\begin{array}{l}\text { - Use simple language to speak with the } \\
\text { participants }\end{array}$ & $\begin{array}{l}\text { - Use simple words when directing the participants. When you } \\
\text { explain to the participants the tasks, process, objectives etc, you } \\
\text { should use a esy vocabulary and you must to speak }\end{array}$ \\
\hline & $\begin{array}{l}\text { - Take note of the times when the } \\
\text { participant asks for help. }\end{array}$ & $\begin{array}{l}\text { - The evaluator mus to take note of the times when the participant } \\
\text { asks for help and it will be showed on the final inform like a } \\
\text { parameter to take on count on the evaluation }\end{array}$ \\
\hline & - Speak slowly and repeat some times & $\begin{array}{l}\text { - Speak slowly and some times is necessary repeat the same idea } \\
\text { to the same participant and trying to make he or she pay attention } \\
\text {, the participants had a problem to concentrate. }\end{array}$ \\
\hline & $\begin{array}{l}\text { - The participant who participated on } \\
\text { the pilot test can participate on the real } \\
\text { test }\end{array}$ & $\begin{array}{l}\text { - It is recommended to execute the complete test from the } \\
\text { beginning, including the first participant who colaborate on the } \\
\text { pilot test because the particpants do not memorize easily. It } \\
\text { should also include the changes that were made to the test plan } \\
\text { after the pilot. }\end{array}$ \\
\hline & $\begin{array}{l}\text { - Take nnot of the all participant } \\
\text { behaviour }\end{array}$ & $\begin{array}{l}\text { - Consider the reactions of the persons being evaluated for each of } \\
\text { the tasks that they complete. It is very important to determine } \\
\text { their satisfaction level and the improvements that could be made } \\
\text { in the next version. We had diferents participants reactions suc } \\
\text { as: smile, sad,angry, worried, thinking long time, complains, }\end{array}$ \\
\hline
\end{tabular}


International Journal of Computer Science, Engineering and Information Technology (IJCSEIT), Vol.7, No.2, April 2017

\begin{tabular}{|c|c|c|}
\hline & & $\begin{array}{l}\text { asks, etc. Every one means important informationn at th } \\
\text { emomento to evaluate. }\end{array}$ \\
\hline & $\begin{array}{l}\text { - Apply } \\
\text { questionaries proposed }\end{array}$ & $\begin{array}{l}\text {-In general, we can see that it was necessary to adapt the SUS } \\
\text { questionnaire for the persons with Down syndrome because it is } \\
\text { a complex survey for participants. SUS was modified to evaluate } \\
\text { the USATESTDOWN process, the guide, which was designed } \\
\text { with the expert tutors who work with the participants daily. }\end{array}$ \\
\hline & $\begin{array}{l}\text { - Solve all of the questions that the user } \\
\text { has during the process, }\end{array}$ & $\begin{array}{l}\text {-It is important because otherweise the participants could not } \\
\text { follow the next step, the answerd could be on a discrete way to } \\
\text { support the participant but it is necessary because they have } \\
\text { limitations to memoriz or understand easily. Don't let the } \\
\text { participant alone. }\end{array}$ \\
\hline & $\begin{array}{l}- \text { Apply the } \\
\text { USATESTDOWN propose as soon as } \\
\text { posible. }\end{array}$ & $\begin{array}{l}\text { - After completing the usability test session with a down syndrome } \\
\text { participant, facilitator needs to ask the participant to answer post } \\
\text { task questionnaire that USATESTDOWN propose as soon as } \\
\text { posible because the particiants use to forgeteasily. }\end{array}$ \\
\hline & $\begin{array}{l}\text { - Ask theparticipant if he/she wants to } \\
\text { colabrate }\end{array}$ & $\begin{array}{l}\text { - Don't push the persons to participate if they don't want, it may } \\
\text { generate a bad atmosphere to work. }\end{array}$ \\
\hline & $\begin{array}{l}\text { - Don't push the participant to anser a } \\
\text { question }\end{array}$ & $\begin{array}{l}\text { - Don't push the persons to answer if they don't want, it may } \\
\text { generate a bad atmosphere to work. }\end{array}$ \\
\hline Documents & $\begin{array}{l}\text {-UsatestDown Demographic Questionary } \\
\text {-UsatestDown SUS Questionary adapted } \\
\text {-UsatestDown SUS Questionary to Tutor }\end{array}$ & $\begin{array}{l}\text { Annexes) } \\
\text { persons with Down Syndrome focused in the whole process } \\
\text { focused in the whole process (Annexes) }\end{array}$ \\
\hline
\end{tabular}

\section{Analyse the collected information}

Table 9: Usatestdown: Analyse the collected information

\begin{tabular}{|c|c|c|}
\hline \multicolumn{3}{|r|}{ USATESTDOWN } \\
\hline Step : & & Analyse the collected information \\
\hline Definition & \multicolumn{2}{|c|}{$\begin{array}{l}\text { Analyze the objective data (times, errors, etc.), the more subjective data (satisfaction questionnaire and } \\
\text { interviews), and all of the data that contributes to understanding the behavior of the evaluated persons } \\
\text { from the usability test. The objective is to identify usability problems and propose improvements. }\end{array}$} \\
\hline \multirow[t]{2}{*}{$\begin{array}{l}\text { Bibliography } \\
\text { Research: }\end{array}$} & $\begin{array}{l}\text { BIBLIOGRAPHY } \\
\text { SUGESTION }\end{array}$ & REAL EXPERIENCE \\
\hline & $\begin{array}{l}\text { The autors J. G. Wishart } \\
\text { proposed the DEVAN } \\
\text { method[41]. }\end{array}$ & $\begin{array}{l}\text { We tried to apply but was too complicated and was focused only to } \\
\text { childrens }\end{array}$ \\
\hline \multirow[t]{5}{*}{ Usatestdown } & $\begin{array}{l}\text { USATESTDOWN } \\
\text { GUIDELINE }\end{array}$ & GOT FROM EXPERIENCE \\
\hline & $\begin{array}{l}\text { - Compare the qualitative } \\
\text { with quealitative dates. }\end{array}$ & $\begin{array}{l}\text { - It is important to analyze the data with all of the parameters collected } \\
\text { from the persons who participated in the usability test. This involves } \\
\text { qualitative content (logs) as well as quantitative (user reactions). It } \\
\text { means the results could be diferent because persons with dow syndrome } \\
\text { have the tendo to be friendly and they will not aswer the questions on a } \\
\text { objective way, they would say the answer the evaluator would like to } \\
\text { hear. For this reason the evaluator sgould conduct an analysis of the part } \\
\text { that appeared qualitatively in the evaluation and the quantitative data } \\
\text { results }\end{array}$ \\
\hline & $\begin{array}{l}\text { - Take specific attention } \\
\text { on applications data logs } \\
\text { to make Statistics, it will } \\
\text { show the real result }\end{array}$ & $\begin{array}{l}\text { - The tool should help the evaluation with logs whoes alow the evaluators } \\
\text { analyse the participants interactions with the mobile device for exampel, } \\
\text { how many times the participant touch the screen, on wich way, up, } \\
\text { down, left, right etc. Finally we could analyse this information in a } \\
\text { quantitative way. }\end{array}$ \\
\hline & $\begin{array}{l}\text { - The collected data by } \\
\text { observing when the } \\
\text { persons performing the } \\
\text { task scenarios sould be } \\
\text { here }\end{array}$ & $\begin{array}{l}\text { - The results should show the collected date during the test sesion, they } \\
\text { are so important to analyse the cualitative part. }\end{array}$ \\
\hline & $\begin{array}{l}\text { - The index indicators } \\
\text { should be clear } \\
\text { explained }\end{array}$ & $\begin{array}{l}\text { - Index as : Success, Satisfaction and Frustration Rate per Task and } \\
\text { Document should be analysed it shows the most information when the } \\
\text { evaluator is working with people with down syndrome, they use to be so } \\
\text { expresive with their face or body behave. This includes; the persons } \\
\text { feeling, fun, ease of use and their satisfaction level towards the game. }\end{array}$ \\
\hline
\end{tabular}


9. Report results to the development team or management.

Table 10: Usatestdown: Report results to the development team or management.

\begin{tabular}{|c|c|c|}
\hline \multicolumn{3}{|c|}{ USATESTDOWN } \\
\hline Step: & \multicolumn{2}{|c|}{ Report results to the development team or management. } \\
\hline Definition & \multicolumn{2}{|c|}{$\begin{array}{l}\text { Prepare a presentation or report to explain the usability problems that were encountered and how they can be } \\
\text { improved. }\end{array}$} \\
\hline $\begin{array}{l}\text { Bibliography } \\
\text { Research: }\end{array}$ & \multicolumn{2}{|l|}{ NO CONTRIBUTIONS } \\
\hline \multirow[t]{6}{*}{ Usatestdown } & USATESTDOWN GUIDELINE & GOT FROM EXPERIENCE \\
\hline & $\begin{array}{l}\text { - All people involve in the test } \\
\text { sesion should be on the } \\
\text { presentacionand give their own } \\
\text { point of view and comments }\end{array}$ & $\begin{array}{l}\text {-The results presentation should be done to all of the members of the } \\
\text { group, with a clear document }\end{array}$ \\
\hline & $\begin{array}{l}\text { - The document to send to the } \\
\text { Design Develop department all the } \\
\text { data logs information should be } \\
\text { included. }\end{array}$ & $\begin{array}{l}\text { - The inform to the Desig an Develop department should include all } \\
\text { the, and with the respective backups such us, aplication logs, } \\
\text { recorded videos, questioanries, etc. }\end{array}$ \\
\hline & $\begin{array}{l}\text { - Make a short and easy to } \\
\text { understand inform to the Directives } \\
\text { people on the centre, they use to } \\
\text { use the information to improve the } \\
\text { education way }\end{array}$ & $\begin{array}{l}\text { - We did a inform with the most important points found on the test } \\
\text { sesion because the centres use this information to improve the way } \\
\text { to teach, but the inform must not have participants personal } \\
\text { information because it must be private }\end{array}$ \\
\hline & $\begin{array}{l}\text { - Save the participants information } \\
\text { on a confidential way after the test } \\
\text { sesion. }\end{array}$ & $\begin{array}{l}\text { - Apply the Ethical Issues in Recruiting Participants, it means follow } \\
\text { the rules that each centre have to manage the participant } \\
\text { information with ethical process. We should safe in a private and } \\
\text { confidential way the collected information. }\end{array}$ \\
\hline & $\begin{array}{l}\text { - Include the old reports if it there } \\
\text { would be from another interation } \\
\text { and make a comparision. }\end{array}$ & $\begin{array}{l}\text { - In the case that the results were not satisfactory, improvements to } \\
\text { the system should be made and it should be executed again, } \\
\text { following the USA TESTDOWN guide. }\end{array}$ \\
\hline
\end{tabular}

\section{a. USATESTDOWN GUIDE}

\section{Establish the tasks}

- Take the participants with the same level of disability.

-The tasks should not have a high complex level. The difficult scale should be of 1 to 3 , where 1 is easier, the task should take 1.

-The session should be done in 10 minute sessions for each person,

-Do not limit to the participants the time.

\section{Write the instructions}

-Use only the oral way to explain the task to the participants

-Ask the participant if he/she is a willing participant.

-Speak slowly and repeat the task

-Perform the session with the participant individually.

\section{Define the test plan}

-The demographic survey must have only general information not lasts names.

-Apply the User satisfaction survey only with 3 answers . USATESRDOWN tets is recommended.

-Don't use documents with text to the participants. If you need to give documents it is better with graphics or don't not use documents

-Write short questions only with 3 answers 
-Write questions focused on the applications and try to make understand the participants how important is to say the truth

-Participation of the expert tutors is required

-The sessions will be facilitated and observed by only one facilitator to one participant

-Persons need to be encouraged to participate and facilitator should stress the value of the child's input and show appreciation and gratitude.

-The educators of people with DS should be present at the moment of perform the session.

- Give the participant the device for long time to execute the game (or task) task at home. Application should have a data log to record.

-Apply at least 2 evaluation methods

-Establish objective metrics with a completion time for the task, error rate, etc.

- The participants should have pre training about the application

-Establish subjective metrics such as success, frustration, satisfaction, etc.

- Schedule a break halfway

-Record videos about the participant sessions but without faces.

-Hold a meeting prior to executing the test

- Observation method needs facilitator to record all children action, behaviours and facial expressions while observing children playing the game.

-The evaluator should evaluate every participant on an individual way.

-Do not use the technique of "thinking out loud"

\section{Run the pilot test}

- Record on video the interaction of the person with the mobile device

-Ask for parents' permission if it is necessary to film faces,

-To the pilot test is necessary only one participant

-The tutors or professors should be present on the evaluation session.

-The facilitator will sit next to the child during the session to take note and solve participant questions

-Two questionnaires need to be assessed, they are proposed for USATESTDOWN

-Post task questionnaire will be conducted right after each test session with the help from the Tutor or Parent

-Take note of the times when the participant asks for help.

-Take a pause

-Use simple words when directing the participant

-Speak slowly slow and sometimes is necessary repeat the same idea

\section{Refine the test plan after analysing the results of the pilot tests.}

-Validate the tasks what the evaluator would you like to change with the Tutors

-Write the changes will be done and explain the reason why it was made.

-It is required a formal document signed by the participants tutor to make changes.

\section{Recruit participants}

-It is necessary that evaluators determine the cognitive disabilities level of the participants that they need, only the age is not a parameter to be on count.

-There should get at least 10 participants to the evaluation 
-Send clear information about the session objective to the Technology Department, if they are interested on the research and they could find an importation to the centre they would contact with the Directives explaining the advantages they could have.

-Evaluator and Tutor should have a meeting to define the participant profile and tutor should recommend the participants profile to make the task that the evaluator proposed.

-The facilitator should ask the participant if he/she wants to collaborate

-Don't push them to finish fast.

-Place should be the same where the participants work

\section{Run the test session}

-Do not complete the final test on the same day as the pilot testing

-Record everything the participant make and all his body behaviour

-Make a pause during the test

-Use simple language to speak with the participants

-Take note of the times when the participant asks for help.

- Speak slowly and repeat some times

-The participant who participated on the pilot test can participate on the real test

- Take not of the all participant behaviour

-Apply USATESTDOWN questionaries' proposed

-Solve all of the questions that the user has during the process,

-Apply the questionaries' USATESTDOWN propose as soon as possible.

-Ask the participant if he/she wants to collaborate

-Don't push the participant to answer a question

\section{Analyse the collected information}

- Compare the qualitative with qualitative dates.

- Take specific attention on applications data logs to make Statistics, it will show the real result

- The collected data by observing when the persons performing the task scenarios should be here

-The index indicators should be clear explained

\section{Report results to the development team or management.}

-All people involve in the test session should be on the presentation and give their own point of view and comments

-The document to send to the Design Develop department all the data logs information should be included.

-Make a short and easy to understand inform to the Directives people on the centre, they use to use the information to improve the education way

-Save the participants information on a confidential way after the test session.

-Include the old reports if it there would be from another interaction and make a comparison. 


\section{b. Questionaries suggested by UsatestDown}

We showed the questionnaires with the following tables.

Table 11: SUS Questionnaire for persons with Down syndrome

\begin{tabular}{|l|l|l|l|}
\hline SUS QUESTIONNAIRE & YES & MAYBE & NO \\
\hline 1. Would you use this application to work? & & & \\
\hline 2. Do you think the application is difficult to use? & & & \\
\hline 3. Do you think the application is easy to use? & & & \\
\hline $\begin{array}{l}\text { 4. Do you think help is necessary in order to use the } \\
\text { application? }\end{array}$ & & & \\
\hline $\begin{array}{l}\text { 5. Do you think the application would be useful for your } \\
\text { work colleagues? }\end{array}$ & & & \\
\hline
\end{tabular}

\section{Open questions}

1. What did you like mostly?......

2. What did you dislike?

3. What did you find easy to do

4. What did you find so diffiut to do ?

Table 12: Demographic Questionnaire example

\begin{tabular}{|l|l|l|l|l|}
\hline ID & Name & Age & $\begin{array}{l}\text { Do you have a } \\
\text { smarth cell } \\
\text { phone? }\end{array}$ & $\begin{array}{l}\text { Did you use } \\
\text { computers ? How } \\
\text { oft? }\end{array}$ \\
\hline 1 & & & & \\
\hline 2 & & & & \\
\hline 3 & & & & \\
\hline
\end{tabular}

Table 13: Formulary Example to Tutor

\begin{tabular}{|l|l|l|l|l|l|l|l|l|}
\hline & & SUCCES & SATISFACTION & FRUSTRATION & SUCCES & SATISFACTION & FRUSTRATION \\
\hline GENDER & $\begin{array}{c}\text { USER } \\
\text { ID }\end{array}$ & \multicolumn{9}{|c|}{ TR } & \multicolumn{4}{|c|}{ TASK N.... } \\
\hline F & 3 & 0 & 0 & 1 & 1 & 1 & 3 \\
\hline F & 4 & 1 & 1 & 1 & 1 & 1 & 1 & 2 \\
\hline M & 6 & 1 & 1 & 1 & 1 & 1 & 3 \\
\hline F & 10 & 0 & & 1 & 1 & 1 & 2 \\
& & & & & & 1 & \\
\hline
\end{tabular}

Table 14: Examples of Metrics to measure the participant satisfaction level

\begin{tabular}{|l|l|l|l|l|l|l|l|l|l|}
\hline User id & $\begin{array}{l}\text { User } \\
\text { Name }\end{array}$ & Age & Gender & $\begin{array}{l}\text { Task } \\
\text { Secuence } \\
\text { No. }\end{array}$ & Evaluator & $\begin{array}{l}\text { Do you } \\
\text { have a } \\
\text { smarth } \\
\text { cellphone } \\
?\end{array}$ & $\begin{array}{l}\text { Ratio of } \\
\text { tasks } \\
\text { completed } \\
\text { correctly } \\
\text { incorrectly } \\
\text { (VIDEOS) }\end{array}$ & $\begin{array}{l}\text { Number of } \\
\text { times } \\
\text { user } \\
\text { expresses } \\
\text { satisfaction } \\
\text { (VIDEOS }\end{array}$ & $\begin{array}{l}\text { Number } \\
\text { times the user } \\
\text { expresses } \\
\text { frustration }\end{array}$ \\
\hline 3 & RR & 28 & MASCULINO & 1 & Doris & SI & & & \\
\hline 3 & RC & 28 & MASCULINO & 1 & Doris & SI & & & \\
\hline 3 & PP & 28 & MASCULINO & 1 & Doris & SI & & & \\
\hline
\end{tabular}


International Journal of Computer Science, Engineering and Information Technology (IJCSEIT), Vol.7, No.2, April 2017

\section{CONCLUSIONS AND FUtURE WORK}

In general, we can see that it was necessary to adapt the SUS questionnaire for the persons with Down syndrome because it is a complex survey for participants. SUS was modified to evaluate the USATESTDOWN process, the guide, which was designed with the expert tutors who work with the participants daily.

In general, it is clear that the guide is viable and can be successfully used and modified to the needs of persons with Down syndrome, with this as an example of a real-world success. It was also evaluated by the expert tutors as part of this process, which was a great help and supported the adaptation of the guide. The participation of the expert tutors is very important as their experience greatly contributed to the implementation of the test, following the guide. Additionally, it is critically important to include the expert tutors with the interaction with the participants'

It is necessary also the previous interactions with the application to create a comfortable and familiar environment so the participants feel safe and trust the process as they are asked questions or doing a task. We recommend that times are not as strict and participants are able to work with as much flexibility as possible. The time parameter set by the first participant to force the second participant to complete the task in the same amount of time was not always produce the same cognitive or memory coefficients.

We suggest an evaluation stage where devices are given back to them to determine how much time is necessary for them to work independently from the tutors and then independent of the application and able to do the activity without the support of a tutor or the application.

\section{REFERENCES}

[1] J. Jadán-Guerrero, L. Guerrero, G. López, D. Cáliz, and J. Bravo, "Creating TUIs Using RFID Sensors-A Case Study Based on the Literacy Process of Children with Down Syndrome," Sensors, vol. 15, no. 7, pp. 14845-14863, 2015.

[2] L. M. Normand, "No Title."

[3] A. Brandão, E. Passos, C. Vasconcelos, A. Conci, E. Clua, P. T. Mourão, and M. Cordeiro, "Stimulating imitation of children with Down syndrome using a game approach," VIII Brazilian Symp. Games Digit. Entertain., pp. 97-100, 2009.

[4] J. R. Joseph S. Dumas, A Practical Guide to Usability Testing.

[5] A. Lepistö, "Usability evaluation involving participants with cognitive disabilities," Proc. third Nord. Conf. Humancomputer Interact. Nord. 04, pp. 305-308, 2004.

[6] J. Nielsen and M. Kaufmann, "Usability Engineering," p. 340, 1993.

[7] J. Nielsen, "Heuristic Evaluation,” Usability Insp. Methods, pp. 25-62, 1994.

[8] A. Brand??o, D. G. Trevisan, L. Brand??o, B. Moreira, G. Nascimento, C. N. Vasconcelos, E. Clua, and P. T. Mour??o, "Semiotic inspection of a game for children with Down syndrome," Proc. - 2010 Brazilian Symp. Games Digit. Entertain. SBGames 2010, no. August 2016, pp. 199-210, 2011.

[9] R. Pal, "On the Lewis-Nielsen model for thermal/electrical conductivity of composites," Compos. Part A Appl. Sci. Manuf., vol. 39, no. 5, pp. 718-726, 2008. 
International Journal of Computer Science, Engineering and Information Technology (IJCSEIT), Vol.7, No.2, April 2017

[10] I. Macedo and D. G. Trevisan, "A Method to Evaluate Disabled User Interaction : A Case Study with Down Syndrome Children,” Univers. Access Human-Computer Interact. Des. Methods, Tools, Interact. Tech. eInclusion, pp. 50-58, 2013.

[11] L. Kumin and J. Lazar, "A Usability Evaluation of Workplace-Related Tasks on a Multi-Touch Tablet Computer by Adults with Down Syndrome,” J. Usability ..., vol. 7, no. 4, pp. 118-142, 2012.

[12] R. Ramli and H. B. Zaman, "Designing usability evaluation methodology framework of Augmented Reality basic reading courseware (AR BACA SindD) for Down Syndrome learner," Proc. 2011 Int. Conf. Electr. Eng. Informatics, ICEEI 2011, no. July, 2011.

[13] F. Adebesin, P. Kotzé, and H. Gelderblom, "The complementary role of two evaluation methods in the usability and accessibility evaluation of a non-standard system," Proc. 2010 Annu. Res. Conf. South African Inst. Comput. Sci. Inf. Technol. - SAICSIT '10, pp. 1-11, 2010.

[14] R. L. Yussof and H. Badioze Zaman, "Usability evaluation of multimedia courseware (MEL-SindD)," Lect. Notes Comput. Sci. (including Subser. Lect. Notes Artif. Intell. Lect. Notes Bioinformatics), vol. 5857 LNCS, pp. 337-343, 2009.

[15] D. Cáliz, L. Martínez, X. Alamán, C. Terán, and R. Cáliz, “ U Sability Testing in Mobile Applications Involving People With Down Syndrome : a Literature Review ,’” ICAIT 2016 Conf., 2016.

[16] Asindown ORG, “Asindown Valencia,” 2017. [Online]. Available: http://asindown.online/. [Accessed: 10-Jan-2017].

[17] M. Corredentora, "Ma. Corredentora," 2017. [Online]. Available: http://mariacorredentora.org/wpmcorg/. [Accessed: 10-Jan-2017].

[18] A. ORG, “Apadema,” 1971. [Online]. Available: http://www.apdema.org/tag/madrid/.

[19] “Fundación PRODIS,” 2016. [Online]. Available: http://www.fundacionprodis.org/. [Accessed: 14Jun-2016].

[20] R. L. Yussof and T. N. S. T. Paris, "Reading Activities Using the Scaffolding in MEL-SindD for Down Syndrome Children," Procedia - Soc. Behav. Sci., vol. 35, no. December 2011, pp. 121-128, 2012.

[21] J. Marco, E. Cerezo, and S. Baldassarri, "Bringing tabletop technology to all: Evaluating a tangible farm game with kindergarten and special needs children," Pers. Ubiquitous Comput., vol. 17, no. 8, pp. 1577-1591, 2013.

[22] "Maria Corredentora Centre," 2016. [Online]. Available: http://mariacorredentora.org/wpmcorg/ . [Accessed: 11-Nov-2016]. 


\section{Authors}

\section{Ing. MSc. Doris Cruz Caliz Ramos.}

- Computer Sciences Engineering

- $\quad$ Master in Management of Information Technology and Communications

National Polytechnic School Ecuador. 2008 - 2012

- International Leadership Training. Germany. 2011 - 2012

- $\quad$ PHD Student in Polytechnic School Madrid. 2013- 2017

- $\quad$ Academic Visitor in Middlesex University London. 2015 - 2016

- Academic Visitor at Bremen University Germany. 2016

- Academic Visitor Karlsruhe Institute of Technology (KIT). Pervasive Computing Systems - TecO 2017

\section{Doctor. Loic Antonio Martinez Normand}

- $\quad$ Professor Department ETSIINF, DLSIIS, Madrid Polytechnic University. 2008 - Today.

- $\quad$ Researcher in Group Investigation on Technology Informatics and Communications: CETTICO.

- $\quad$ President Sidar Foundation. 2002 - Today
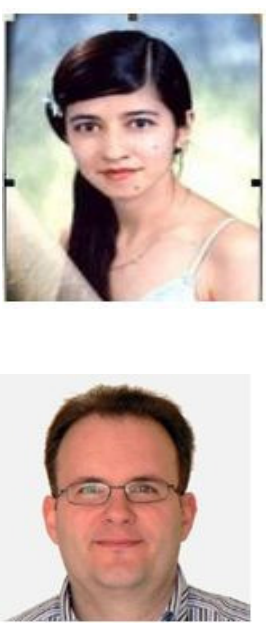

\section{Ing.MSc. Richarth Harold Caliz Ramos.}

- Master in Management of Information Technology and Communications MSc, final mark: cum laude. National Polytechnic School (EPN), Quito, Ecuador (Fall 2008-Winter 2010)

- Telecommunications and Electronics Engineering, final mark: cum laude. National Polytechnic School (EPN), Quito, Ecuador (Fall 1995-Winter 2002)

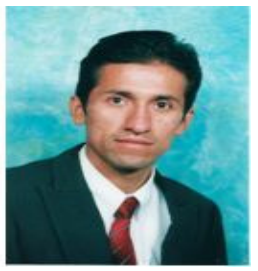

